ETNIK : Jurnal Ekonomi - Teknik

ISSN: 2808-6694 (Online);2808-7291 (Print)

Jurnal Homepage https://etnik.rifainstitute.com

\title{
PERTUMBUHAN EKONOMI DAN INFLASI DI INDONESIA PADA MASA PANDEMI
}

\author{
Eka Purnama Sari, Fadia Salsabila Rahmawan, Nurul Jannah
}

Universitas Islam Negri Sumatera Utara

\section{Informasi Artikel}

Histori Artikel:

Diterima

07 Desember 2021

Direvisi

15 Desember 2021

Diterbitkan 20 Desember 2021

\section{Email Author:}

epurnamasari705@gmail.com

fadiasalsabila2000@gmail.com

jnurul1992@gmail.com

\begin{abstract}
The Covid-19 pandemic has caused recessions in many countries around the world. This occurred after economic growth in the first and second quarters of 2020. Several countries experiencing recession were Singapore, South Korea, Germany, Japan, France, Hong Kong, and the United States. If the economic growth in each quarter is also negative, Indonesia will experience a recession. The Central Statistics Agency (BPS) noted that Indonesia's economic growth rate fell to minus (5.32\%) in the second quarter of 2020. Previously, Indonesia's economic growth in the first quarter of 2020 was $2.97 \%$ or started to slow down. Inflation is a tendency to increase the price of goods and services in general which takes place continuously which will lead to a decrease in people's purchasing power, especially for low-income groups. Therefore, it is hoped that there will be control of the rate of inflation, especially during the Covid-19 pandemic which has had an impact on Indonesia's macro conditions. This observation discusses the Impact of the Covid-19 Pandemic on Indonesia's Inflation Rate, aiming to determine the effect of the Covid-19 Pandemic on the Inflation Rate in Indonesia. In this writing, the researcher uses library research, namely in the process of collecting data, it is not necessary to go into the field directly but take various reference sources that support this research. Observation results show that in March 2020 there was an inflation of $2.96 \%$ year on year (yoy), with the increase in the price of gold jewelry as well as some food prices which experienced a drastic increase
\end{abstract}

Keyword- Economic Growth, Inflation, Covid-19 Pandemic

\begin{abstract}
ABSTRAK
Pandemi Covid-19 menyebabkan resesi di banyak negara di dunia. Hal ini terjadi setelah pertumbuhan ekonomi pada triwulan I dan II tahun 2020. Beberapa negara yang mengalami resesi adalah Singapura, Korea Selatan, Jerman, Jepang, Prancis, Hong Kong, dan Amerika Serikat. Jika pertumbuhan ekonomi pada tiap triwulan juga negatif, Indonesia akan mengalami resesi. Badan Pusat Statistik
\end{abstract}


(BPS) mencatat laju pertumbuhan ekonomi Indonesia turun menjadi minus $(5,32 \%)$ pada triwulan II-2020. Sebelumnya, pertumbuhan ekonomi Indonesia pada triwulan I-2020 sebesar 2,97\% atau mulai melambat. Inflasi merupakan kecenderungan naiknya harga barang dan jasa pada umumnya yang berlangsung secara terus menerus yang akan menyebabkan menurunnya daya beli masyarakat, khusus golongan berpendapatan rendah. Oleh karena itu, diharapkan adanya pengendalian laju Inflasi, terlebih lagi pada saat Pandemi Covid-19 yang telah memberikan dampak terhadap kondisi makro Indonesia. Observasi ini membahas tentang Dampak Pandemi Covid-19 Terhadap Tingkat Inflasi Indonesia, bertujuan untuk mengetahui pengaruh Pandemi Covid-19 terhadap Tingkat Inflasi di Indonesia. Dalam penulisan ini peneliti menggunakan penelitian kepustakaan yaitu dalam proses pengambilan datanya tidak perlu terjun ke lapangan secara langsung tetapi mengambil berbagai sumber refernsi yang mendukung penelitian ini Hasil observasi menunjukkan bahwa pada bulan Maret 2020 terjadi inflasi sebesar $2,96 \%$ year on year (yoy), dengan naiknya harga emas perhiasan serta beberapa harga pangan yang mengalami kenaikan yang cukup drastis

Kata Kunci - Pertumbuhan Ekonomi, Inflasi, Pandemi Covid 19

\section{PENDAHULUAN}

Organisasi Kesehatan Dunia (WHO) menjelaskan bahwa Corona Virus (COVID 19) adalah virus yang menginfeksi sistem pernapasan. Infeksi virus ini disebut COVID19. Penyakit yang disebabkan oleh virus corona berkisar dari flu biasa hingga penyakit yang lebih serius seperti Middle East Respiratory Syndrome (MERS-CoV) dan Severe Acute Respiratory Syndrome (SARS-CoV). Sejauh ini, 188 negara telah mengkonfirmasi bahwa mereka telah terinfeksi virus corona baru. Penyebaran virus corona yang telah menyebar ke seluruh dunia telah berdampak pada perekonomian Indonesia, baik dari sisi perdagangan, investasi maupun pariwisata. Penyakit Coronavirus 2019 (COVID-19) telah menginfeksi jutaan orang di seluruh dunia. Hal ini memiliki dampak yang besar pada perekonomian dan dapat menyebabkan kemerosotan ekonomi suatu negara. Beberapa kegiatan produksi terhenti karena kurangnya permintaan yang dapat merangsang kegiatan produksi, mengakibatkan meningkatnya pengangguran dan jutaan orang jatuh miskin

Peneliti menganalisis pengaruh indikator makro ekonomi yaitu, pertumbuhan ekonomi dan inflansi. Pada triwulan I-2020, pertumbuhan ekonomi nasional masih positif sebesar 2,97\%. Namun pada triwulan II, pertumbuhan ekonomi sudah minus 5,32\%. Negara-negara maju, seperti Amerika Serikat, Italia, Perancis, Jerman, dan Korea Selatan juga mengalami hal yang sama, bahkan pertumbuhan ekonominya sudah mencapai minus 17\%-20\% (AlAli 2020). Kemenkeu telah merilis berita bahwa pertumbuhan ekonomi pada triwulan III-2020 berkisar minus $2,9 \%$ hingga minus $1,1 \%$. Hal ini menunjukkan bahwa Indonesia akan memasuki resesi ekonomi (Kemenkeu 200a).

Pemerintah Indonesia telah melakukan rangkaian program melalui stimulus ekonomi untuk mengantisipasi supaya negara tidak terpuruk jauh dalam resesi ekonomi. Di sisi lain, pemerintahjugaberupaya keras untuk menghentikan penyebaran wabah Covid-19. Program Pembatasan Sosial Berskala Besar (PSBB) yang diterapkan sejak Maret hingga Mei 2020, kemudian dilanjutkan dengan kebijakan memberlakukan 
adaptasi situasi normal baru (new normal era adaptation) sejak Juni 2020, ternyata dinilai kurang efektif mengurangi penyebaran wabah Covid-19. Perekonomian tidak bertambah baik, dan penyebaran wabah tidak kunjung berkurang.

Disisi lain Dampak pandemi Covid-19 terhadap kondisi makro Indonesia salah satunya yaitu terjadi inflasi. Di Indonesia pada bulan Maret 2020 terjadi inflasi sebesar $2,96 \%$ year on year (yoy), dengan naiknya harga emas perhiasan serta beberapa harga pangan yang mengalami kenaikan yang cukup drastis (Majidah, Yousida, and Abdurakhman 2021). Inflasi merupakan salah satu indikator ekonomi makro yang dapat digunakan untuk melihat stabilitas perekonomian suatu negara, karena perubahan dalam indikator ini akan berdampak langsung terhadap dinamika pertumbuhan ekonomi.

\section{METODE}

Penelitian ini bertujuan untuk mengetahui Pengaruh Indikator Ekonomi Makro Terhadap Pertumbuhan Ekonomi Di Indonesia Pada Masa Pandemi. Dalam penulisan ini peneliti menggunakan penelitian kepustakaan yaitu dalam proses pengambilan datanya tidak perlu terjun ke lapangan secara langsung tetapi mengambil berbagai sumber refernsi yang mendukung suatu penelitian ini. Jenis penilitian yang dilakukan pada penilitian ini merupakan penelitian kualitatif. Metode kualitatif merupakan metode yang dilakukan untuk mengumpulkan data, kemudian data dianalisis secara kualitatif yang didukung dengan teori dan wawasan terhadap penelitian yang dilakukan untuk mendapatkan hasil yang jelas dan bermakna (Shidiq and Choiri 2019).

\section{HASIL DAN PEMBAHASAN}

Dalam tiga bulan pertama (kuartal pertama) Januari hingga Maret 2020, virus Covid 19 menyebar dengan cepat di Indonesia dan berdampak cukup besar terhadap kegiatan perekonomian Indonesia. Perubahan persediaan menjadi penyumbang negatif terbesar terhadap pertumbuhan, dengan nilai $-0,33 \%$, diikuti oleh ekspor jasa $(-0,32)$ dan konsumsi LNPRT (lembaga nonprofit yang melayani rumah tangga) $(-0,05)$. Hal ini menunjukkan bahwa pandemi telah menekan kegiatan produksi di industri jasa dan manufaktur. Pertumbuhan ekonomi Indonesia yang positif ini disebabkan oleh pertumbuhan beberapa sektor usaha, di antaranya sektor jasa keuangan dan asuransi tumbuh 10,67\%, diikuti oleh sektor jasa kesehatan dan kegiatan sosial sebesar 10,39\%, dan sektor informasi dan komunikasi tumbuh sebesar 9,81\%

Pemberlakuan PSBB (Pembatasan Sosial Berskala Besar) membuat roda perekonomian hampir terhenti. Per 21 Juni 2020, jumlah kasus positif Covid 19 di Indonesia sebanyak 45.891. Sedangkan pasien sembuh di Indonesia sebanyak 18.404 dan kematian mencapai 2.465.Pertumbuhan ekonomi di Indonesia.

\section{Pertumbuhan Ekonomi Di Indonesia}

Perekonomian nasional dari produk domestik bruto (PDB) sebanyak Rp3.687,7 triliun atas dasar harga berlaku dalam triwulan II-2020, sedangkan PDB atas dasar harga (tahun dasar 2010) sebanyak Rp2.589,6 triliun. Dampak pandemi Covid 19 sampai Agustus 2020 atau triwulan II2020 menampakan pertumbuhan ekonomi domestik turun 5,32\% dibandingkan triwulan II-2019 (yony). Dibandingkan Desember 2019 (kuartal ke-4) sebelum pandemi, ekonomi tumbuh 4,97\% (BPS2020a).Pada awal pandemi, Maret 2020 (triwulan 1), ekonomi tumbuh 2,97\% (year-onyear), namun melambat dibandingkan kuartal sebelumnya (BI 2020). Laju pertumbuhan ini 
merupakan pertumbuhan ekonomi terendah sejak 2001, jauh lebih tinggi dari perkiraan Kementerian Keuangan Indonesia dan Bank Indonesia (Modjo 2020) yang memperkirakan pertumbuhan ekonomi $4 \%$ hingga 5\% pada triwulan I-2020. rendah.

Laju pertumbuhan ekonomi pada triwulan I-2020 lebih rendah 2,1\% dibandingkan dengan triwulan I-2019 yang sebesar 5,07\%. Sementara itu, pertumbuhan ekonomi nasional semester I-2020 menyusut $-1,26 \%$ dibandingkan semester I-2019 (c-to-c). Kontraksi pertumbuhan ekonomi pada triwulan II (year-on-year) cukup parah mencapai -5,32\% (Wuryandani 2020). Berdasarkan uraian tersebut, dapat disimpulkan bahwa pandemi Covid-19 telah memberikan dampak yang cukup besar terhadap penurunan pertumbuhan ekonomi nasional. Jika rencana pemulihan ekonomi yang telah dicanangkan tidak berjalan mulus, maka pertumbuhan ekonomi diperkirakan akan terus negatif.

Pertumbuhan ekonomi positif dan negatif dalam tiga periode (sebelum pandemi dan selama pandemi) didorong oleh beberapa sektor utama. Sebelum pandemi, tiga industri yang tumbuh paling cepat adalah jasa lainnya, jasa korporasi, dan teknologi informasi (Tabel 1).Pada awal epidemi, yaitu pada triwulan 1 tahun 2020, industri jasa keuangan, layanan kesehatan, dan informasi dan komunikasi menjadi penopang pertumbuhan ekonomi. Sementara itu, selama masa pandemi (triwulan kedua 2020), industri utama yang menyebabkan ekonomi nasional menyusut adalah transportasi dan penyimpanan $(30,84 \%)$, diikuti oleh akomodasi dan katering, dan manufaktur, masing-masing 11,02\% dan 6,19\%. . Di masa pandemi, triwulan pertama dan kedua tahun 2020, industri informasi dan komunikasi merupakan industri yang sangat tangguh karena masih menjadi salah satu penyumbang PDB nasional

Berdasarkan sumber pertumbuhan, BPS (2020b) melaporkan bahwa dampak pandemi Covid19 pada triwulan II-2020 telah menyebabkan perubahan sumber pertumbuhan ekonomi. Sektor pertanian dalam arti luas yaitu pertanian, kehutanan dan perikanan merupakan sumber pertumbuhan kedua setelah sektor informasi dan komunikasi dengan kontribusi sebesar 0,29\%. Selain itu, jika dibandingkan antara triwulan II-2020 dengan triwulan I-2020 (triwulan I), terdapat 3 sektor dengan pertumbuhan positif tertinggi di antara 17 sektor penyumbang PDB. Sektorsektor tersebut adalah pertanian, kehutanan dan perikanan menyumbang 16,2 \%, perdagangan 3 , $\%$ dan penyediaan air bersih, pengolahan limbah, limbah dan daur ulang 1,28\%. (Gambar 1).

\section{Tabel 1.Pertumbuhan dan Sector Utama Contributor PDB Indonesia Tahun 2019 dan 2020}

\begin{tabular}{|c|c|c|c|}
\hline Uraian & Triwulan IV-2019 & Triwulan I-2020 & Triwulan II-2020 \\
\hline $\begin{array}{l}\text { A. Pertumbuhan } \\
(y-o n-y)\end{array}$ & $4,97 \%$ & $2,97 \%$ & $-5,32 \%$ \\
\hline $\begin{array}{l}\text { B. Sektor yang } \\
\text { Memiliki } \\
\text { pertumbuhan/ } \\
\text { Kontraksi } \\
\text { Tertinggi }\end{array}$ & $\begin{array}{l}\text { 1. Jasa lainnya } \\
(10,78 \%) \\
\text { 2. Jasa } \\
\text { Perusahaan } \\
(10,49 \%) \\
\text { 3. Infokum } \\
(9,71 \%)\end{array}$ & $\begin{array}{l}\text { 1. Jasa keuangan } \\
\text { asuransi } \\
(10,67 \%) \\
\text { 2. Jasa kesehatan } \\
\text { dan kegiatan } \\
\text { sosial }(10,39 \%) \\
\text { 3. Infokum } \\
(9,81 \%)\end{array}$ & $\begin{array}{l}\text { 1. Transportasi } \\
\text { dan pergu- } \\
\text { dangan } \\
(-30,84 \%) \\
\text { 2. Penyedia } \\
\text { akomodasi dan } \\
\text { makan minum } \\
(-22,02 \%) \\
\text { 3. Industri } \\
\text { pengolahan } \\
(-6,19 \%)\end{array}$ \\
\hline
\end{tabular}




\begin{tabular}{lccc}
$\begin{array}{l}\text { C. Sumber } \\
\text { pertumbuhan } \\
(y-\text {-on- } y)\end{array}$ & $\begin{array}{l}\text { 1. Industri } \\
\text { Pengolahan }\end{array}$ & $\begin{array}{c}\text { 1. Infokum } \\
(0,53 \%)\end{array}$ & $\begin{array}{c}\text { 1. Infokum } \\
(0,58 \%)\end{array}$ \\
& $\begin{array}{l}(0,80 \%) \\
\text { 2. Perdagangan }\end{array}$ & $\begin{array}{c}\text { 2. Jasa asuransi } \\
(0,44 \%)\end{array}$ & $\begin{array}{c}\text { 2. Pertanian, } \\
\text { kehutanan, }\end{array}$ \\
& $(0,61 \%)$ & 3. Industri & dan perikanan \\
& 3. Konstruksi & pengolahan & $(0,29 \%)$ \\
$(0,58 \%)$ & $(0,29 \%)$ & 3. Real estat \\
& & & $(0,07 \%)$ \\
\hline
\end{tabular}

\section{Gambar 1. PDB Per Sektor Pada Triwulan II-2020 (q-to- $q$ )}

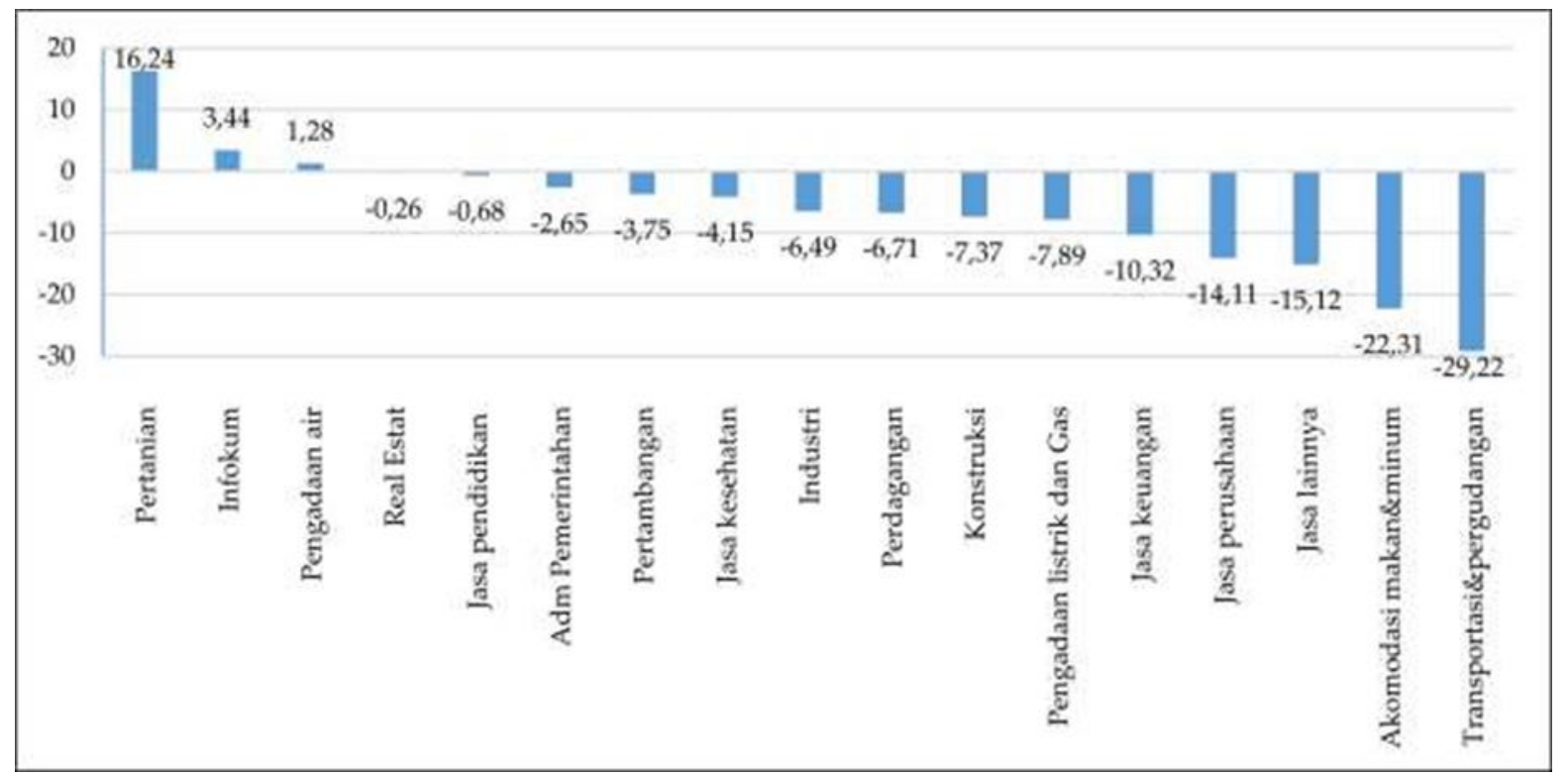

Sumber : BPS (2020)

\section{Inflasi}

Banyak kerusakan yang disebabkan oleh COVID-19 telah mempengaruhi perekonomian Indonesia, dan pembangunan ekonomi suatu negara terutama ditujukan untuk memastikan kesejahteraan rakyatnya melalui pertumbuhan ekonomi yang tinggi dan distribusi pendapatan yang adil. hal ini sangat beda dengan situasi di Indonesia pada tahun 1997/1998, dimana krisis nilai tukar awal berubah menjadi krisis perbankan, hingga menjalar menjadi krisis politik dan sosial yang sangat besar pengaruhnya terhadap rakyat Indonesia. Tingginya tingkat inflasi kemudian membuat daya beli masyarakat menurun, terutama bagi kelompok masyarakat berpenghasilan rendah. Perubahan jumlah uang dapat mempengaruhi tingkat bunga dan fungsi konsumsi, sehingga jumlah uang menyebabkan perubahan permintaan agregat.

Contohnya adalah pedagang yang sering berjualan di tempat ramai seperti pasar yang kini tidak berjualan lagi karna karena pasar saat ini di tutup untuk mengurangi peningkatan penyebaran virus corona. Oleh karena itu, para pebisnis tidak memiliki pendapatan yang stabil karena orang harus terus menghidupi dirinya sendiri. Dengan adanya covid19 ini, masyarakat hampir tidak bisa memenuhi kebutuhan hidupnya, jadi bagaimana kita bisa membantu mereka yang saling menguntungkan, bisa membantu mereka yang membutuhkan. Covid19 berdampak negatif bagi perekonomian masyarakat Indonesia

Sistem ekonomi adalah sistem yang digunakan oleh suatu negara untuk mendistribusikan sumber dayanya kepada individu dan organisasi di suatu negara tersebut. Namun sejak pandemi ini, negara mengalami krisis ekonomi yang dinilai lebih lemah dari tahun-tahun sebelumnya, 
bahkan menurut pernyataan Menteri Keuangan, pertumbuhan ekonomi bisa turun hingga 2,5\% hingga $0 \%$, yang bisa terjadi ketika strategi hedging yang baik dan tepat tidak diterapkan. untuk mengatasinya, dan sekarang seluruh negeri telah menambah perawatan intensif untuk 20 tenaga kesehatan dan jumlah bidang medis mencapai 6,1 triliun dan pada saat ini dan itu menjadi perhatian 'ekonomi global' Dalam pembicaraan dengan gubernur bank dan menteri keuangan ASEAN, termasuk negara-negara ASEAN, menteri mengatakan bahwa Covid19, termasuk ekonomi nasional, dipertaruhkan dan sekarang kita fokus pada kesehatan. penting, tetapi sektor lain juga diperhatikan dan tidak ditinggalkan karena saling mendukung. Untuk pertama kalinya sejak Covid19, Indonesia akan menjadi negara Asia pertama yang menerbitkan obligasi global (sertifikat utang), yang bertujuan untuk menjaga pembiayaan yang aman dan meningkatkan cadangan devisa bank-bank Indonesia.(Hanoatubun, 2020).

Berikut ini tabel perekembangan inflasi di Indonesia sebelum pandemi Covid19 tahun 2019 dan sesudah pandemi Covid-19 tahun 2020:

Tabel 2. Perkembangan Tingkat Inflasi Indonesia Tahun 2019

\begin{tabular}{|c|c|}
\hline Tanggal & Data Inflansi \\
\hline Januari & $2.81 \%$ \\
\hline Februari & $2.57 \%$ \\
\hline Maret & $2.48 \%$ \\
\hline April & $2.83 \%$ \\
\hline Mei & $3,32 \%$ \\
\hline Juni & $3,28 \%$ \\
\hline Juli & $3,32 \%$ \\
\hline Agustus & $3,49 \%$ \\
\hline September & $3.39 \%$ \\
\hline Okotober & $3,13 \%$ \\
\hline November & $3 \%$ \\
\hline Desember & $2.72 \%$ \\
\hline
\end{tabular}

Sumber: Bank Indonesia, 2019

Tabel 3. Perkembangan Tingkat Inflasi Indonesia Tahun 2020

\begin{tabular}{|c|c|}
\hline Tanggal & Data Inflansi \\
\hline Januari & $2.68 \%$ \\
\hline Februari & $2.98 \%$ \\
\hline Maret & $2.96 \%$ \\
\hline April & $2.67 \%$ \\
\hline Mei & $2,19 \%$ \\
\hline Juni & $1,96 \%$ \\
\hline Juli & $1,54 \%$ \\
\hline Agustus & $1,32 \%$ \\
\hline September & $1,42 \%$ \\
\hline Okotober & $1,44 \%$ \\
\hline November & $1,59 \%$ \\
\hline Desember & $1,69 \%$ \\
\hline
\end{tabular}

Sumber: Bank Indonesia, 2020 


\section{SIMPULAN}

Pertumbuhan ekonomi Indonesia yang positif ini disebabkan oleh pertumbuhan beberapa sektor usaha, di antaranya sektor jasa keuangan dan asuransi tumbuh 10,67\%, diikuti oleh sektor jasa kesehatan dan kegiatan sosial sebesar 10,39\%, dan sektor informasi dan komunikasi tumbuh sebesar 9,81\% Pemberlakuan PSBB (Pembatasan Sosial Berskala Besar) membuat roda perekonomian hampir terhenti. Laju pertumbuhan ini merupakan pertumbuhan ekonomi terendah sejak 2001, jauh lebih tinggi dari perkiraan Kementerian Keuangan Indonesia dan Bank Indonesia (Maryanti, Netrawati, and Faezal 2019) yang memperkirakan pertumbuhan ekonomi 4\% hingga 5\% pada triwulan I-2020. Sementara itu, selama masa pandemi (triwulan kedua 2020), industri utama yang menyebabkan ekonomi nasional menyusut adalah transportasi dan penyimpanan (30,84\%), diikuti oleh akomodasi dan katering, dan manufaktur, masing-masing $11,02 \%$ dan 6,19\%. Di masa pandemi, triwulan pertama dan kedua tahun 2020, industri informasi dan komunikasi merupakan industri yang sangat tangguh karena masih menjadi salah satu penyumbang PDB nasional Berdasarkan sumber pertumbuhan, BPS (2020b) melaporkan bahwa dampak pandemi Covid19 pada triwulan II-2020 telah menyebabkan perubahan sumber pertumbuhan ekonomi. Banyak kerusakan yang disebabkan oleh COVID-19 telah mempengaruhi perekonomian Indonesia, dan pembangunan ekonomi suatu negara terutama ditujukan untuk memastikan kesejahteraan rakyatnya melalui pertumbuhan ekonomi yang tinggi dan distribusi pendapatan yang adil. Untuk mengatasinya, dan sekarang seluruh negeri telah menambah perawatan intensif untuk 20 tenaga kesehatan dan jumlah bidang medis mencapai 6,1 triliun dan pada saat ini dan itu menjadi perhatian 'ekonomi global' Dalam pembicaraan dengan gubernur bank dan menteri keuangan ASEAN, termasuk negara-negara ASEAN, menteri mengatakan bahwa Covid19, termasuk ekonomi nasional, dipertaruhkan dan sekarang kita fokus pada kesehatan.

\section{BIBLIOGRAFI}

[BI] Bank Indonesia. 2020. Sinergi, transformasi, dan inovasi menuju Indonesia maju. Laporan Perekonomian Indonesia Maret 2020. Jakarta (ID): Bank Indonesia.

[BPS] Badan Pusat Statistik. 2020a. Berita resmi statistik No. 17/02/Th. XXIV, 5 Februari 2020. Jakarta (ID): Badan Pusat Statistik.

[BPS] Badan Pusat Statistik. 2020b. Berita resmi statistik No 64/08/Th.XXII, 5 Agustus 2020. Jakarta (ID): Badan Pusat Statistik.

Badan Pusat Statistik.(n.d.). Retrieved March 11, 2021, from https://www.bps.go.id/subject/3/inflasi.html

Bank Indonesia, April 2020, Statistik Ekonomi dan KeuanganIndonesia

Bank Indonesia. (n.d.). Retrieved March 26, 2021, from https://www.bi.go.id/id/statistik/indikator/data-inflasi.aspx

AlAli, Musaed S. 2020. "Risk Velocity and Financial Markets Performance: Measuring the Early Effect of COVID-19 Pandemic on Major Stock Markets Performance.” International Journal of Economics and Financial Research 6(64): 76-81.

Majidah, Laila, Imawati Yousida, and M. Zaidan Abdurakhman. 2021. "Jieb : Jurnal Ilmiah Ekonomi Bisnis Issn Online 2615-2134.” Jurnal Ilmiah Ekonomi Binis Issn Online 7(1): 2615-2134. 
Maryanti, Sri, Iga Oka Netrawati, and Faezal Faezal. 2019. "Menggerakan Perekonomian Melalui Pemulihan Usaha Dan Industri Mikro Kecil Menengah Pasca Bencana Gempa Bumi Di Nusa Tenggara Barat." Media Bina Ilmiah 14(4): 2321.

Shidiq, Umar, and Miftachul Choiri. 2019. 53 Journal of Chemical Information and Modeling Metode Penelitian Kualitatif Di Bidang Pendidikan. http://repository.iainponorogo.ac.id/484/1/METODE PENELITIAN KUALITATIF DI BIDANG PENDIDIKAN.pdf. 